\title{
Sensibilidades jurídicas, saber e poder: bases culturais de alguns aspectos do direito brasileiro em uma perspectiva comparada
}

\section{Roberto Kant de Lima}

\section{(2) OpenEdition \\ Journals}

Edição electrónica

URL: http://journals.openedition.org/aa/885

DOI: $10.4000 /$ aa. 885

ISSN: 2357-738X

Editora

Programa de Pós-Graduação em Antropologia Social (UnB)

Edição impressa

Data de publição: 1 dezembro 2010

Paginação: 25-51

ISSN: 0102-4302

Refêrencia eletrónica

Roberto Kant de Lima, «Sensibilidades jurídicas, saber e poder: bases culturais de alguns aspectos do direito brasileiro em uma perspectiva comparada», Anuário Antropológico [Online], v.35 n.2 | 2010 , posto online no dia 16 outubro 2015, consultado o 28 abril 2021. URL: http://journals.openedition.org/ aa/885 ; DOI: https://doi.org/10.4000/aa.885

\section{(c)}

Anuário Antropológico is licensed under a Creative Commons Atribuição-Uso Não-Comercial-Proibição de realização de Obras Derivadas 4.0 International. 


\title{
Sensibilidades jurídicas, saber e poder: bases culturais de alguns aspectos do direito brasileiro em uma perspectiva comparada*
}

\author{
Roberto Kant de Lima \\ Departamento de Antropologia/UFF
}

Aquele sentimento de justiça que mencionei acima - a que chamarei, ao deixar paisagens mais conhecidas na direção de lugares mais exóticos, de sensibilidade jurídica - é, portanto, o primeiro fator que merece a atenção daqueles cujo objetivo é falar de uma forma comparativa sobre as bases culturais do direito. Pois essas sensibilidades variam, e não só em graus de definição; também no poder que exercem sobre os processos da vida social, frente a outras formas de pensar e sentir (dizem que, ao deparar-se com as leis antipoluição, a Toyota contratou mil engenheiros e a Ford mil advogados); ou nos seus estudos e conteúdos específicos. Diferem, e profundamente, nos meios que utilizam - nos símbolos que empregam, nas estórias que contam, nas distinções que estabelecem para apresentar eventos judicialmente. É possível que fatos e leis existam universalmente; mas sua polarização provavelmente não (GEERTZ, Clifford. “O saber local: fatos e leis em uma perspectiva comparativa”. In: . O Saber Local: novos ensaios em antropologia interpretativa. 8. ed. Petrópolis: Vozes, 2006. p. 261, 262; grifo meu).

\section{Introdução: a pesquisa}

Neste artigo, irei discutir alguns dos resultados de pesquisas que venho realizando nos últimos 20 anos, referentes à compreensão e à aplicação deste conceito sensibilidade jurídica - a diferentes contextos jurídicos ocidentais. Evidentemente, seguirei aqui os passos de tantos pesquisadores que me precederam. Entretanto, com o passar dos anos, fui lentamente chegando a algumas conclusões, que me levam a propor alternativas e correções nas proposições que tanto eu como outros fizemos sobre as questões em pauta, pois as etnografias realizadas, embora inspiradas nessas discussões, foram abrindo portas para que outros aspectos das sensibilidades jurídicas ocidentais se explicitassem.

Inicialmente, devo recapitular os passos da pesquisa; depois, apresentar os dados etnográficos construídos e apontar as insuficiências de alguns aspectos dos modelos teóricos interpretativos vigentes; finalmente, propor outros modelos, de maior potencial interpretativo, cuja crítica, certamente, não tardará. 
A curiosidade pelas sensibilidades jurídicas ocidentais se iniciou, para mim, de forma bastante ingênua para um antropólogo, embora certamente ainda faça sentido para leigos e juristas. Tratava-se de uma categoria que nomeava uma instituição jurídica, aparentemente situada em duas tradições - ou sistemas jurídicas e judiciais distintas, a do Brasil e a dos Estados Unidos: o júri.

Assim, comecei meus estudos empíricos fazendo a etnografia de processos judiciais no Brasil (1981-1984), que incluíam colocar sob descrição suas fases preliminares - como o inquérito policial - e finais - como as penitenciárias e as prisões - de acordo com a recomendação de minha banca de qualificação de doutorado em realização nos Estados Unidos.

Nessa ocasião, uma surpresa: quando nos Estados Unidos, estava constantemente consultando a biblioteca da Faculdade de Direito de Harvard sobre o assunto "Tribunal do Júri” no Brasil, para construir meu projeto de qualificação. Quando voltei ao Brasil, não me preocupei em trazer minhas fontes bibliográficas, pois, afinal, estava voltando ao lugar onde os livros foram escritos e publicados. Qual não foi minha surpresa quando encontrei imensa dificuldade de comprá-los ou consultá-los em bibliotecas públicas e, mesmo, de localizá-los, só conseguindo ter acesso a eles, depois de muito tempo, solicitando a amigos e conhecidos que me emprestassem seus originais para copiar. Nessa ocasião, lembrei-me muito de minha própria formação jurídica universitária, na Faculdade de Direito da UFRGS, em Porto Alegre, que foi praticamente toda realizada com o apoio da biblioteca do pai de um de meus colegas, que colocou apartamento e escritório disponíveis para oferecer-nos o acesso aos seus livros. Voltarei a esta questão.

Após esse período, voltando aos EUA, passei outro (1985-1986) dedicado a ler a literatura jurídica sobre o jury trial e a escrever minha tese de doutorado, a qual versou apenas sobre os dados construídos sobre o inquérito policial no Brasil, por absoluta falta de tempo para colocar sob descrição todo o sistema observado e suas correspondentes instituições nos EUA, em função do esgotamento dos prazos da CAPES e da Universidade em que trabalhava.

Desta primeira fase da pesquisa restou a certeza de que, embora se utilizando das mesmas categorias jurídicas, as instituições - ou institutos, na classificação jurídica - em muito pouco se assemelhavam: o trial by jury, na versão dos EUA, representava, por um lado, um direito constitucional universal de todos os cidadãos que se julgavam injustamente acusados, tanto em casos civis como em casos criminais graves; de outro, um dever de seus concidadãos de se tornarem disponíveis para julgá-los, sendo escolhidos de comum acordo pelas partes, como árbitros que vão decidir, em uma discussão conjunta e secreta, seu destino, uma vez requisitados aleatoriamente entre os membros da lista eleitoral do lugar. Já o "Tribunal do Júri” brasileiro era apenas mais uma fase processual de um processo criminal obrigatório para todos os acusados, em casos de crimes intencionais (dolosos) contra a vida 
humana, em que os acusados eram julgados por um grupo de cidadãos escolhidos de antemão pelo juiz e sorteados dessa lista - à moda do trial by jury inglês sem se comunicarem entre si.

Entretanto, havia algumas sutilezas nessa importação de categorias jurídicas. A primeira delas até hoje distorce os resultados do trabalho de muitos colegas que se dedicam a estudar homicídios, porque, na concepção clássica dos estudos sobre crimes, este é o que apresentaria menor subnotificação, em função dos cadáveres que são o resultado de sua prática. Entretanto, no Brasil, há crimes intencionais contra a vida humana que não são classificados como homicídios e que são submetidos a outro processo judicial diante de um juiz singular: são os chamados latrocínios, em que a morte é uma consequência de um crime praticado contra o patrimônio.

Ora, por que o homicídio, categoria de registro criminal das mais confiáveis, significando um crime intencional contra a vida humana, recebe duas classificações no Código Penal (Brasil, 2001), que conduzem a dois procedimentos penais distintos? Uma, a do artigo 121, leva os acusados de homicídio ao Tribunal do Júri; a outra, a do art. 157, parágrafo $3,{ }^{1}$ leva os acusados de latrocínio ao julgamento pelo juiz singular. A resposta mais aparente é a de que os procedimentos processuais penais variam em função das intenções das pessoas envolvidas, e não de acordo com os resultados de suas ações. Pode-se também inferir que, em certos casos, quando o crime se verifica entre pessoas, a classificação é de homicídio, registrado em primeiro lugar na parte do Código Penal que define os crimes contra a pessoa, mesmo quando relacionado a outros crimes (inciso V). Quando se verifica entre proprietários e seus expropriadores, classifica-se como latrocínio, crime contra o patrimônio, segundo o Código Penal (Brasil, 2001). Entretanto, para além das constatações óbvias de que o Direito Penal de um país capitalista é seletivo e protege os proprietários, ainda assim caberia perguntar por que o acusado é submetido a diferentes processos, um diante do juiz singular e o outro diante de um júri? ${ }^{2}$ Adiante voltarei a esta questão.

De volta ao Brasil, fui me apropriar da literatura jurídica brasileira sobre o processo criminal, tendo em vista o que tinha aprendido sobre o trial by jury dos EUA. No entanto, na defesa de minha tese e na discussão de um trabalho obrigatório para a qualificação, reiteradamente me foi dito que faltaria uma experiência empírica com o campo jurídico do criminal justice system dos EUA para que eu pudesse formular adequadamente minha perspectiva comparativa. Foi assim que em 1990 permaneci durante seis meses em Birmingham, Alabama, e em San Francisco, Califórnia, por conta de bolsa da USIS e da Comissão Fulbright, fazendo pesquisa de campo, respectivamente, com a polícia e a defensoria pública.

Dessas observações - em San Francisco, quase-participante, pois fui apresentado como antropólogo e advogado por meu colega, George Bisharat, também antropólogo e advogado, que trabalhava, na época, no Public Defender's Office, a defensoria pública de San Francisco - a primeira diferença que me saltou aos 
olhos foi a impossibilidade de trabalhar, em um mesmo contexto, com os órgãos e as instituições envolvidos nos processos policiais e judiciais de acusação e de defesa, respectivamente. Em Birmingham, onde estagiava com a polícia, na Divisão de Entorpecentes (Vice), quando convidado por um advogado criminal a fazer uma visita a seu escritório, recebi imediatamente uma advertência do capitão que havia se responsabilizado por mim na instituição: para continuar a pesquisa com a polícia, não poderia ter relações com seus adversários, os advogados criminais, uma vez que poderia haver, por meu intermédio, vazamento voluntário ou involuntário de informações e observações que eu estava realizando junto à instituição policial. Em San Francisco, já mais atento, percebia que eram muito formais e superficiais as relações entre os advogados da defensoria e os promotores, embora entre os defensores o ambiente fosse de muito companheirismo.

Ora, isto diferia em muito da experiência que eu havia tido em meu trabalho de campo no Brasil onde, em mais de uma ocasião, pude tomar chope, após os julgamentos do Tribunal do Júri, com promotores, juízes e advogados criminais, sendo que em uma dessas também um réu absolvido no júri e jurados sentaram-se à mesa. Pareceu-me, portanto, que havia questões éticas diferentes em ambos os contextos que mereciam mais atenção. Voltarei a este ponto.

Finalmente, a partir de meados de 1990, por várias circunstâncias, pude me aproximar, como professor, orientador e coordenador em pós-graduações stricto sensu e lato sensu, de profissionais que trabalhavam na área de justiça criminal e segurança pública. Experiência riquíssima, que permitiu que eu pudesse colocar à prova minhas observações do sistema de justiça criminal e segurança pública no Brasil, prescrevendo a leitura e discutindo meus textos com esses profissionais, estimulando-os a refletirem sobre suas práticas e a produzirem academicamente sobre o tema (Miranda e Lima, 2008; Pires e Eilbaum, 2009; Mota e Miranda, 2010)

Aqui, várias diferenças, a começar pelo contraste de sua bipartição, pois, oficial e legalmente, os profissionais de justiça criminal (promotores, juízes) não o são de segurança pública (policiais, agentes penitenciários, guardas municipais, bombeiros etc.) e vice-versa, ao contrário daqueles que trabalham no criminal justice system, categoria que se refere ao conjunto das instituições: polícia, district attorneys, juízes, advogados, agentes penitenciários e agentes encarregados de fiscalizar os prisioneiros que se acham em livramento condicional ou os acusados que têm seu julgamento suspenso.

Esse diálogo também me permitiu perceber diferenças fundamentais nas formas de produção e reprodução do conhecimento com alunos que integravam a polícia civil e a polícia militar, estes últimos, muitas vezes, também formados em direito: na área jurídica e militar, a forma dogmática e instrucional predominava, como que inculcando, consciente e inconscientemente, verdades que deviam ser absorvidas, ao invés de conhecimentos que deviam ser assimilados reflexiva 
e criticamente, como é o caso do ensino e da pesquisa em ciências sociais. De certa forma, a reprodução do conhecimento universitário nessas áreas (Faculdades de Direito e Academias de Polícia Militar e Civil) reproduz as formas institucionais de produção e reprodução do saber jurídico emilitar, seja na caserna, seja no tribunal. Essa forma dogmática e instrucional, entretanto, apoiava-se fortemente na lógica do contraditório, que se explicita pela promoção de um dissenso infinito, o qual só se interrompe através de uma autoridade externa às partes, que lhe dá fim e declara uma tese vencedora e a outra, vencida.

Distingue-se, assim, das formas de expressão das lógicas adversárias de produção da verdade, dominantes nas áreas acadêmicas e científicas, fundadas na busca de consensos provisórios sobre fatos que se constroem pela reflexão e a explicitação das diferentes perspectivas dos envolvidos, em um processo de argumentação demonstrativa, que visa ao convencimento de todas as partes legítimas envolvidas no processo: aqui, atingir o consenso entre os pares é fundamental para validar o conhecimento. ${ }^{3}$

De alta relevância para a pesquisa foi também a experiência comparada que se estendeu para além dos Estados Unidos - especialmente na Argentina, Canadá e França - através de um conjunto de convênios e projetos que coordenei em colaboração com meus colegas do Programa de Pós-Graduação em Antropologia e do Núcleo Fluminense de Estudos e Pesquisas, ambos da UFF, além de outros, ligados a diferentes instituições. Nessas oportunidades participei de debates, fiz palestras e visitas a instalações policiais e judiciárias, observando a configuração de seus espaços e, ainda, lecionei cursos para alunos de universidades estrangeiras com disciplinas e tópicos atinentes a este tema, tendo também contato com pesquisadores juniores e seniores locais, que enriqueceram minha perspectiva comparada. Alguns, mesmo, publicados no Brasil por minha iniciativa (por exemplo, Garapon \& Papadopoulos, 2008).

\section{A questão das sensibilidades jurídicas ocidentais}

Certamente, a contribuição de Clifford Geertz ao estudo comparado do direito é de extrema relevância. Antes de seu inspirado texto, do qual retirei a epígrafe do artigo (Geertz, 2006:261, 262), os textos metodológicos mais utilizados na área, salvo raras exceções, reproduziam os dilemas da generalização na comparação antropológica, ora referindo-se à impossibilidade de tradução das categorias nativas, ora fazendo sua extensão a contextos a ela estranhos, como havia criticado, há muito, Godelier, no que tocava ao mau uso da teoria na economia e na antropologia econômica (Davis, 1973; Godelier,1968).

Com a sua proposta de comparar as diferenças entre os sistemas de significados, buscando eventuais equivalências, o método proposto por Geertz enfatiza o contexto das instituições e seu significado local, que lhe emprestam a legitimidade necessária para que produzam seu efeito ordenador. 
Ao definir o direito como uma parte normativa da sociedade - um "modo de vida” normativo (Lima, 2009:89-126) - retira-o do dilema de considerá-lo ora reflexo dela, ora véu que a recobre e impede sua visão completa, à guisa de uma ideologia mistificadora, perspectivas que obscurecem, mais do que esclarecem, seu significado e que são próprias, respectivamente, das propostas teóricas e metodológicas funcionalistas e marxistas stricto sensu, frequente e majoritariamente utilizadas no campo do direito.

No entanto, a perspectiva de que o direito é um saber local coloca em discussão a questão das raízes de sua legitimidade, para Geertz, em seu entendimento, fundada por aqueles que escolhem lhe dever obediência, ou que a ela são obrigados, como no caso descrito de Regregg. Interessante é que esta perspectiva é exatamente aquela da tradição enunciada por alguns juristas da common law dos Estados Unidos, onde até mesmo se suscitou a extinção das Faculdades de Direito, no século XIX, porque o direito, afinal, não passava de regras sociais institucionalizadas, que todos deviam compreender e às quais deviam ter acesso garantido, e não mediado por nenhuma instituição universitária (McCart, 1964).

Como já argumentei em outras oportunidades, este, por exemplo, não é o ponto de vista de outra sensibilidade jurídica ocidental, aquela da civil law tradition, que funda sua legitimidade ${ }^{4}$ em uma racionalidade abstrata, muito mais do que na razoabilidade que as decisões detenham para todos os implicados. Por isso mesmo, considera que os julgamentos técnicos, efetuados por magistrados, são melhores do que os julgamentos das pessoas comuns, que não têm acesso a um saber jurídico especializado e que, portanto, seriam dotadas de uma razoabilidade subalterna.

Por isso, não há trial by jury em países que se afinam com esta sensibilidade. No máximo, há escabinados, órgãos julgadores colegiados, compostos por leigos e especialistas que julgam certos casos em conjunto. No Brasil, a existência do Tribunal do Júri chama a atenção por isso mesmo, porque não é encontrável nos sistemas da civil law. Entretanto, progressivas restrições foram colocadas ao seu funcionamento, desde a introdução do modelo inglês entre nós, como forma de julgamento criminal universal, no primeiro Código de Processo Penal do Brasil Imperial, de 1832. Estas restrições culminaram por reduzir sua competência para julgar apenas crimes intencionais contra a vida humana, com exceção dos latrocínios, que estão classificados no Código Penal (Brasil, 2001) como crimes contra o patrimônio. Finalmente, em 1938, os jurados foram proibidos de se comunicarem entre si para chegar a seu veredicto: essa comunicação pode anular o julgamento e não mais a reunião dos jurados é realizada em uma sala secreta, como no trial by jury, mas a votação deve ser secreta, em resposta a perguntas formuladas pelo juiz com a participação da defesa e da acusação - os quesitos - em sala em que estão presentes, além dos jurados, o juiz, o promotor, o advogado de defesa e o meirinho. 
Esse viés, associado a muitos outros, permite inferir que a referência comparativa de Geertz, quando se refere à sensibilidade jurídica ocidental, reside na sua vertente da common law, em especial na versão dos EUA. Não é outra a razão de sua discussão sobre as relações entre fato e lei, fact e law, possível apenas nas tradições em que os processos adversários de argumentação, de inclusão e exclusão de evidências (exclusionary rules), de direct examination ou examination-in-chief e cross-examination, definem judicialmente quais são os facts em litígio, consensualizando-os, como ele faz quando interpreta o caso Regregg. As evidences são consensuais, a sua credibilidade é que é discutível: essa credibilidade, após seu teste nos rituais de examination, transforma-as em fatos e, posteriormente, em provas que o juiz declara para o conhecimento dos jurados, antes de se retirarem para a sua deliberação (Kaplan, 1972). No trial by jury, quando não se convencem as partes previamente, em um acordo até a última hora possível entre elas, a decisão acaba sendo consensualizada pelos seus árbitros, os jurados, na sala secreta, onde argumentam e extraem a sua verdade coletiva: o verdict.

Acresce ainda que a categoria law, em inglês, refere-se a direito e lei, categorias jurídicas distintas na civil law, que expressam esse divórcio possível entre a legislação e o direito, entre a legitimidade do modo de vida jurídico, da elaboração legislativa e da aplicação do direito. No fundo, os objetivos dos códigos organizados e promulgados pelo Legislativo, onde estão os representantes do povo, são no sentido de prever determinados comportamentos e antecipar decisões para conflitos possíveis, com a finalidade de tolher a liberdade decisória dos membros do Judiciário, seus intérpretes. Na tradição da common law, quem faz a lei é a sociedade, não o Estado, e lei e direito são inseparáveis (Weber, 1978). Voltarei a esta questão.

Ora, no direito brasileiro, por exemplo, o processo não se volta para consensualizar os fatos, para estabelecer quais são os fatos, nem o que ficou provado efetivamente. Pelo contrário, através da lógica do contraditório, que propõe um dissenso infinito e veda qualquer consenso entre as partes, os fatos e as provas são determinados pela autoridade interpretativa do juiz: é ele quem vai escolher dentre os inúmeros indícios contraditórios trazidos ao processo quais o convencem e quais não (Figueira, 2008). Depois de convencido através desse mecanismo intuitivo, ele justifica sua sentença: é o que se chama de livre convencimento motivado do juiz ${ }^{5}$ (Mendes, 2010).

De outra perspectiva, podemos ver que a legitimidade da sensibilidade jurídica ocidental pode não residir no seu entendimento dos fatos. É assim que Bourdieu, ao descrever a crença na legitimidade da missa em latim, que os fiéis não entendem, mas acreditam, atribui a eficácia do ritual não à sua compreensão, mas à sua eficácia simbólica, que nada tem de entendimento, mas de compreensão contextual (Bourdieu, 1996) 
Também Bourdieu não parece dar importância às distinções entre essas duas tradições e às diferenças de significado de seus processos de formação de decisões. Em seu texto A Força do Direito (Bourdieu, 2009) mistura as duas tradições judiciais ocidentais, ao considerar veredictos e sentenças como equivalentes. Ora, veredictos - de vere dictum, dizer a verdade - estão ligados às decisões dos jurados, árbitros que combinam, ou votam, seus veredictos sobre determinado assunto. Já sentenças - que os juristas acreditam ter sua origem etimológica no verbo latino sentire (Mendes, 2010) - são a consequência de decisões tomadas intuitivamente, mas depois necessariamente racionalizadas e justificadas, emitidas por juízes profissionais, ou não, mas sempre autocráticos.

Seria muito complicado explicar aqui porque as duas tradições, originadas da mesma fonte, que os historiadores das ideias jurídicas situam por volta dos séculos IX a XI (por exemplo, Berman, 1983, 2003; Foucault, 2005), se opõem. Em síntese, trata-se fundamentalmente de duas ideias bastante distantes, como já disse acima, sobre o fundamento da legitimidade da decisão judicial e da administração institucional de conflitos, que produz verdades judiciárias: uma atribuída às partes litigantes ou a seus árbitros, outra atribuída a técnicos profissionais ou juristas especializados (Lima, 1995).

Por outro lado, Michel Foucault, familiar aos cientistas sociais, mas também aos juristas mais contemporâneos, tem uma proposta para identificar a sensibilidade jurídica ocidental, a qual, aliás, coincide em muitos pontos com a versão de Harold Berman, jurista dos Estados Unidos, embora sejam quase que opostas as consequências que ambos retiram desta perspectiva comum.

Para Foucault, a sensibilidade jurídica contemporânea começa a se formar fundamentada na instituição do inquest, própria da tradição eclesiástica e voltada para a aferição de fatos passados através de perguntas de resposta obrigatória. Esta forma de produzir verdades jurídicas, já conhecida na Grécia, está interessada no testemunho daqueles que têm notícia dos fatos em litígio. E vai conviver com outras formas de produção da verdade jurídica, fundada na revelação divina e na qual não interessam os fatos, mas apenas aquele que demonstra que tem razão, através de testes ou provas que solicitam a intervenção sobrenatural: é o sistema da prova legal. ${ }^{6}$ Segundo o autor, o sistema de produção da verdade pelo inquest é inicialmente colocado à disposição daqueles que o solicitam às autoridades mais poderosas, em concorrência com o sistema de provas, próprio da justiças senhoriais e eclesiásticas. Exemplo dessa disputa ficou popularizado pelo livro de Umberto Eco, O Nome da Rosa (1980). No entanto, o inquest pouco a pouco vai sendo apropriado pela realeza, através da figura do procurador e, juntamente com a tomada das armas, articula o processo de centralização do poder real e suas consequências políticas, sociais e econômicas. 
Esta é a maneira como o poder jurídico passa a se exercer, repressivamente, sobre fatos ocorridos no passado e reconstituídos através da versão do inquérito, caracterizando a sensibilidade jurídica ocidental contemporânea. Para Foucault, inclusive, torna-se a principal forma de controle social, até que condições sociais, políticas e econômicas dão lugar a outra forma de controle social, a outro regime de produção de verdade, fundado no exame, que é um dispositivo extrajurídico de controle social, estruturado a partir de fenômenos sociais administrativos (lettres de caché) na França e na defesa comunitária contra o poder real, na Inglaterra. Este sistema de controle social está voltado para a vigilância da sociedade, visando prever o comportamento virtual, futuro e possível das pessoas, e não para fatos passados. Seus efeitos não são repressivos, mas disciplinares, pois as pessoas que se encontram sob sua influência internalizam os valores que a elas, por esse meio não-repressivo, se impõem.

Entretanto, a versão foucaultiana dessa trajetória das formas de produção da verdade jurídica encontra severas dissonâncias na versão de Berman. Embora este concorde com Foucault sobre o papel do surgimento do inquest enquanto modo de apropriação de poder e sustentáculo de uma incipiente realeza, voltada para a produção de verdade através da reconstituição pelos testemunhos do que ocorreu, a forma que este inquest tomou, desde o começo, foi a do trial by jury, não a do inquérito. E o trial by jury é uma reconstituição dos fatos feita por aqueles que deles têm conhecimento, as testemunhas, reunidas entre si para, ao final das discussões, dizerem a verdade. Verdade deles, que irá produzir efeitos jurídicos sobre os envolvidos.

Assim, enquanto Foucault vê o inquest transformar-se no inquérito, um instrumento de poder à disposição do soberano, que o instaura através de seu procurador para apurar as faltas contra ele ou, posteriormente, praticadas contra o Estado, Berman vê o inquest converter-se no trial by jury, instituição que se coloca à disposição daqueles que, considerando-se injustamente acusados, não desejam que seus litígios sejam submetidos às cortes eclesiásticas ou senhoriais, nas quais vige o regime de verdade das provas legais, e convocam seus vizinhos e pares como testemunhas que decidem o litígio dizendo a sua verdade.

Vemos, assim, surgir uma dupla interpretação para a instituição do inquest, ora fonte cristalizadora do poder que se absolutiza, ora defesa contra, exatamente, este poder: pois é assim que a tradição jurídica da common law interpreta as diferentes instituições daí oriundas, como Carta Magna, Bill of Rights e outras limitações do poder real de julgar, que acabariam por substanciar-se no contemporâneo trial by jury, no julgamento dos cidadãos pelos seus pares, outros cidadãos.

Não sem, entretanto, uma significativa mutação, de que não encontrei explicação consistente em nenhum dos textos consultados: no início do século XIX, exatamente quando Foucault identifica as condições de transformações econômicas, políticas e 
sociais que culminariam na substituição do inquérito pelo exame, eis que o trial by jury se torna: 1. hegemônico, sendo as outras formas de prova legal juridicamente abolidas na common law; 2. transforma o right to stay mute no non-incriminatory right, fazendo com que o silêncio dos acusados se converta em uma declaração de not guilty e, portanto, submetendo todos os acusados ao processo; 3 . faz com que os jurados não possam mais ser aqueles que testemunharam, passando eles a ser aqueles que, não tendo conhecimento prévio do litígio, apenas assistem ao trial by jury - julgamento oral que somente então se transcreve - e que se reúnem secretamente para dar seu veredicto.

Esta transformação da instituição altera radicalmente, no meu entender, seu significado: realmente, retira do saber local o controle das decisões, pois as testemunhas não são mais as que decidem; impede que os acusados que não se declaram culpados não possam mais se submeter a la peine forte et dure, que termina por matá-los, mas livrava seus bens e sua família dos efeitos de uma condenação (Parry, 1975); e transforma as antigas testemunhas em expectadores, que passam a exercer, dentro do sistema judicial, um papel de vigilância que, nos termos de Foucault, era extrajudicial, mas que desta forma vai se consolidar judicialmente no sistema do trial by jury. E, simbolicamente, funcionaria com o mesmo caráter disciplinar, pois se constitui em um julgamento social, de fatos apurados diante de representantes da sociedade, e não do Estado, chamados para proferir um julgamento sobre seus concidadãos. Muito diferente do inquérito, no qual juízes togados, funcionários do Estado, aplicam a lei do Estado, que reprime e pune os erros dos transgressores de acordo com critérios especializados.

A questão é que essa tradição do inquest apresenta, no Brasil, uma terceira versão. Os juristas brasileiros, apoiados em autoridades do campo, relatam o surgimento da inquirição-devassa como o processo de produção da verdade em Portugal, em casos de crimes graves, oriundo dessa mesma forma de valorização do testemunho e de busca da reconstituição dos fatos passados. Porém, enquanto o trial by jury e o inquérito, nas versões de Berman e de Foucault, são procedimentos públicos, a inquirição é sigilosa e escrita. Mais, enquanto o Inquest/trial by jury era iniciado originalmente pelos acusados - tendo sido, na versão foucaultiana, apropriado depois pelo Procurador - em Portugal, desde o início, há a possibilidade de o juiz agir ex-officio, isto é, por iniciativa própria (Almeida Junior, 1920).

Aparentemente, nosso formato processual foi elaborado e reelaborado pelos juristas no decorrer do século XIX, quando se verificaram três grandes reformas processuais penais em nosso país, nas décadas de 1830, 1840 e 1870 . Essas reformas iniciaram-se com a proposta de um modelo processual semelhante ao inglês, instituindo o juiz de paz e, no processo penal, o júri de acusação e o júri de sentença para todos os casos criminais, na década de 30 (Flory, 1981). Esta proposta logo foi substituída na década de 40 , quando se criou a figura do delegado, que era 
um juiz, e instituiu-se uma jurisdição própria para julgar crimes de polícia, que hoje se chamariam crimes de menor potencial ofensivo. Já em 70, separou-se a justiça da polícia e instituiu-se o inquérito policial, nos termos de uma inquirição-devassa do direito processual português, mas também como a inquisitio é descrita na legislação canônica.

Este procedimento constava de uma investigação preliminar, administrativa, enquanto ainda não havia acusação pública, para determinar os fatos objeto do conflito. Sua diferença de uma investigação preliminar, presente em muitos sistemas judiciários, é que ela resultava em autos de um inquérito, escrito e sigiloso, registrado em um cartório - portanto, de caráter puramente inquisitorial que posteriormente, segundo seus resultados, seria encaminhado ao Judiciário pela autoridade policial.

Em 1920, o jurista João Mendes de Almeida Júnior, figura proeminente do campo, na época e até hoje, no Brasil, assim conceitua idealmente os dois modelos, o acusatório - em que a acusação é pública desde o início - e o inquisitório em que a acusação é, inicialmente, escrita e sigilosa - e defende as virtudes de um modelo "misto", que foi o adotado na década de 70:

" 1 . O sistema acusatório admite, em geral, uma acusação formulada no ingresso da instrução, instrução contraditória, defesa livre e debate público entre o acusador e o acusado, ao passo que o sistema inquisitorial procede a pesquisas antes de qualquer acusação, substitui a defesa o interrogatório do indigitado, ao debate oral e público as confrontações secretas das testemunhas e, em geral, a instrução escrita e secreta às informações verbais.

$2^{\circ}$. O sistema acusatório, subordinando-se ao método sintético, afirma o fato e, enquanto não o prova, o acusado é presumido inocente; o sistema inquisitório, subordinando-se ao método analítico, não afirma o fato, supõe a sua possibilidade, presume um culpado, busca e colige os indícios e as provas.

$3^{\circ}$. O sistema acusatório propõe-se a fazer entrar no espírito do juiz a convicção da criminalidade do acusado; o sistema inquisitório propõe-se a fornecer ao juiz indícios suficientes para que a presunção possa ser transformada em realidade.

$4^{\circ}$. Enfim, um preocupa-se principalmente do interesse individual lesado pelo processo, outro preocupa-se principalmente do interesse público lesado pelo delito.“(Almeida Junior, 1920:250, v.l, grifos meus).

Mais, para ele:

"O sistema inquisitório contém elementos que não podem ser repelidos, tanto assim que foi, nos séculos XIII a XVIII uma garantia de justiça e liberdade. Quando o homem de condição humilde estava exposto às arbitrariedades dos fortes, ricos e poderosos, não lhe era fácil comparecer ante as justiças senhoriais para 
acusar sem rebuço, sem constrangimento e sem o temor e a quase certeza da vingança; o Direito Canônico, opondo ao procedimento acusatorial o procedimento inquisitório, foi o protetor da fraqueza perseguida e o adversário da força tirânica; se os abusos desnaturaram a instituição, causando mais tarde males superiores aos benefícios, isso não exige a abolição do sistema e sim a criação de cautelas para o seu aproveitamento.” (Almeida Junior, 1920:250, 251, v.1, grifos meus).

Entretanto, não é isto que o código canônico diz; muito pelo contrário, afirma que o sigilo é importante para proteger a honra dos poderosos das injúrias daqueles que não a possuem, pois segundo Garcia Barberena e Alonso Moran, "la inquisición siempre debe ser secreta y há de praticarse con muchísima cautela, para que no se difunda el rumor del delito ni se ponga en peligro el bueno nombre de nadie" (Cânone número 1943, 1964:668).

Portanto, enquanto o direito canônico associa o sigilo do inquérito à proteção da honra de certos indivíduos, o direito processual penal brasileiro do século XIX associa-o à proteção dos fracos contra os poderosos, ${ }^{7}$ e o direito processual brasileiro contemporâneo associa-o à proteção da intimidade dos cidadãos acusados. ${ }^{8}$

Vê-se, assim, que investigações preliminares - protegidas pelo sigilo, mas capazes de produzir um instrumento cartorial com fé pública contra o acusado, feito à revelia deste, na versão da inquirição-devassa/inquérito policial - estão de qualquer modo, seja para proteger aqueles de boa reputação, seja para proteger os fracos, associadas à superioridade do Estado sobre a Sociedade, à desigualdade entre os segmentos da sociedade - poderosos e não-poderosos, com honra e sem honra - e à cautela de um Estado "tutor" em tornar públicos os conflitos para não ferir a intimidade das pessoas. No Brasil, aparentemente, os conflitos com suposta relevância penal devem passar preliminarmente pelo crivo dos funcionários do Executivo - a Polícia Civil ou Judiciária - sob a forma de um inquérito escrito e sigiloso, cujo conhecimento se reserva às autoridades competentes, que deverão então decidir se tornam, ou não, as acusações públicas para os acusados que, de indiciados no inquérito, se tornam réus de uma ação criminal obrigatória quando denunciados pelo promotor de justiça.

Diante desta breve exposição, constata-se que o modelo do inquest, consensual, raiz de nossa sensibilidade jurídica ocidental, fundado na reconstituição do passado através do recolhimento de testemunhos, desdobrou-se em pelo menos três versões: o trial by jury, o inquérito e a inquirição (Lima, 1991).

Esta constatação, aqui superficialmente argumentada, mas fruto de etnografia consistente tanto no que tange aos textos jurídicos e aos dados arquivísticos, como às observações diretas e participantes nos referidos sistemas empíricos, sugere a insuficiência das explicações aventadas para expressar a eficácia e a legitimidade dos 
saberes locais que articulam os sistemas jurídicos empíricos estudados. Passo, então, a sugerir uma classificação desses sistemas e, posteriormente, a discutir algumas de suas relevantes implicações nos modelos para (Geertz, 1989) administração institucional de conflitos e de controle social, especialmente em nossa sociedade.

\section{Os modelos jurídicos ideais das sensibilidades jurídicas ocidentais}

A questão é óbvia: nesse caso, deve-se falar de uma ou de mais de uma sensibilidade jurídica? A meu ver, as diferenças entre estes dois modelos jurídicos que reivindicam sua origem comum na tradição jurídica ocidental, que se inicia com o inquest, diferem não só entre si, mas também do modelo brasileiro, que insiste em radicar sua origem principalmente na longínqua Roma, ocultando sua vinculação com as transformações políticas, sociais e econômicas que acompanharam sua produção e reprodução.

Os textos dos juristas dos Estados Unidos, por exemplo, fazem questão de mesclar as tradições romanas ora com as gregas e as protestantes (Dawson, 1960), ora com as católicas (Berman, 1983, 2003). Mas a tradição brasileira, não só a que está escrita nos livros, mas a que se ouve nos bancos escolares, até hoje privilegia as origens romanas e insiste em distanciar a inquisitio canônica da inquirição.

Isto seria bastante irrelevante se não estivesse tão evidente a relação umbilical das formas de produção da verdade no direito processual penal brasileiro com aquelas da tradição eclesiástica católica. Há muitos exemplos que se fundam, todos, na busca de uma suposta verdade real (do Rei?), que seria a base da sentença e da certeza do juiz para senti-la (Mendes, 2010). Mas acho que o mais explícito é o caso da confissão: enquanto, por exemplo, em francês usa-se a categoria processual aveu para se diferenciar a confissão judiciária da conféssion católica, a categoria confissão no Brasil é usada em ambos os contextos, para significar coisas que seriam, na prática, bem diferentes. Pois uma confissão judicial, nos termos da lei, consiste na admissão de culpa por aquilo de que se é acusado. Admite-se a culpa por conveniência, sem que a alma seja subjugada, nem a mente. Na confissão católica, religiosa, o que está em jogo é a salvação, a vida extraterrena. Por isso mesmo, quem não confessa pode mentir, pois optou por não salvar sua alma, por salvar o corpo. Por isso, a confissão é atenuante, mas só vale se coincidir com o que a justiça já sabe. Assim, a confissão só é a Rainha das Provas quando coincide com o que se sabe. Daí, não pode ser aceita quando difere do que está escrito, de antemão, nos autos sigilosos da inquirição, considerando-se a mesma suspeita e, até mesmo, passível de incriminação como autoacusação.

O que se disse acima não tem pouca consequência para a ética da advocacia: porque o réu pode mentir para se defender - os advogados preferem o eufemismo de apresentar outra versão para os fatos; mas como no processo em que impera a lógica do contraditório não há fatos, só há versões e indícios, ocorre que uma versão 
cartorial produzida pelo inquérito policial tem fé pública, e a outra, a do réu que se defende, não tem. E no processo penal brasileiro, as alegações do réu que não estão conformes aos autos do inquérito têm que ser provadas, o que caracteriza seu ethos inquisitorial. Assim, se supõe sempre que o réu mente para defender-se, o que macula de falsas todas as alegações que não coincidem com a apuração sigilosa e prévia, que tem fé pública. Onde esta inquirição preliminar e secreta, feita pelo Executivo, não existe, o sentido da confissão é outro e assemelha-se muito mais a um testemunho ou a uma submissão à verdade imposta pelo Estado. ${ }^{9}$

Esta questão gera não pouca confusão e deslegitimação entre os que se aventuram no sistema, voluntária ou obrigatoriamente. Diferente da regra dos EUA, onde o silêncio corresponde a uma declaração de not guilty, o silêncio no Brasil está associado ao conhecido provérbio: "quem cala consente". Por isso mesmo, os acusados não devem permanecer em silêncio, pois "quem não deve não teme", como diz outro ditado, frequentemente invocado pela polícia e pela acusação. Ocorre que, embora a Constituição de 1988 (Brasil, 1989) tenha consagrado esse direito ao silêncio, não criminalizou a mentira dita em público como perjúrio ou obstrução da justiça: a mentira, no Brasil, só é penalizada nos chamados crimes contra a honra. Por isso, os acusados podem inventar impunemente falsas explicações para seus atos e mesmo falsos fatos para confundir a acusação, sendo nisso acompanhados por seus advogados. ${ }^{10}$

Sobre esta questão, um exemplo. Quando estava ministrando curso de extensão em Nova Iguaçu sobre justiça criminal e segurança pública, para alunos do curso de direito e membros do Batalhão da Polícia Militar local, na Universidade Iguaçu - UNIG, durante a aula de um experiente defensor público, professor de Processo Penal da UNIG, a que eu estava presente como coordenador do curso, ocorreu fato significativo. $O$ defensor pedia aos soldados da Polícia Militar que não omitissem nada, nem mentissem, quando da elaboração dos autos de flagrante, feitos pelos policiais civis, porque muitas vezes aquele era o único documento que se possuía sobre os fatos ocorridos e, se ele não correspondesse realmente aos fatos, ficava muito difícil fazer a defesa dos acusados.

Nesse momento, um aluno pede para falar e ocorre o seguinte diálogo:

- Aluno: Professor, o sr. é um defensor público, não é?

- Professor: Sou, sim.

- A: Então o sr. está pedindo para a gente não mentir, mas o sr. mente para defender os seus constituintes, não é?

- P: Eu não minto, eu construo uma versão da defesa, porque de acordo com a Constituição (Brasil, 1989) todos têm direito à defesa, ao contraditório, e eu sou obrigado a defender meu cliente. 
- A: Mas o sr. é um funcionário público, não é? E como é que o sr. mente?

- P: Sou. O que eu faço é criar uma mentira técnica a que o acusado tem direito para poder se defender das acusações.

- A: Então quer dizer que o sr. é pago para mentir?

Nesta altura, o professor repete a explicação, com a citação de artigos que se referem ao princípio do contraditório, presente em vários textos legais, inclusive na Constituição (Brasil, 1989), insistindo em que a sua mentira técnica era legítima e legal. $\mathrm{O}$ aluno, entretanto, insiste:

- A: Então, professor, já que o sr. é obrigado a mentir, poderia me explicar o fundamento moral da sua mentira?

- P: Bom, eu realmente não sei, mas o professor Roberto Kant, aqui presente, certamente sabe.

Ao que eu, depois de hesitar, respondo que se trata provavelmente da associação entre o processo penal secular e o ethos católico, que pretende, com a confissão, salvar a alma até dos condenados, como se vê nas cenas dos Autos de Fé da Inquisição. Se o acusado não confessa e é culpado, vai para o inferno, para a danação eterna. Então, no caso do processo, o réu pode se livrar da pena secular, mas não escapará da justiça divina pois, quando morrer, irá para o inferno.

Nesse momento, ouço um comentário, baixinho, ao meu lado, de um aluno para outro: "Não digo para você, fulano? Se acaba tudo no inferno, para que esse trabalho? Manda eles logo para o inferno e pronto!”.

Já no processo judicial da common law, a confissão é pouco útil para o processo: representa apenas uma concordância explícita - pré-processual ou, quando processual, extintora do processo - com uma determinada acusação, que foi previamente negociada entre as partes. Se o acusado não admite a responsabilidade pelo que lhe imputam, exige um processo. Se consegue negociar o tipo penal pelo qual vai ser acusado, faz a declaração de guilty correspondente, responsabilizando-se, simplesmente, pelo ato categorizado no tipo penal negociado.

Um caso, entre muitos presenciados durante meu trabalho de campo com a Defensoria Pública de San Francisco, ilustra esta questão. Tratava-se de um chicano, trabalhador mexicano "boia-fria", de pequena estatura, que tentara entrar em uma boate gay na cidade, tendo sido impedido de fazê-lo pelo segurança, que era um cidadão americano de alta estatura e bastante forte, sob a alegação de que a boate era um clube privado e exigia, entre outras coisas, que seus frequentadores estivessem vestidos com adornos corporais de couro, específicos da moda de então em San Francisco. O chicano insistiu em entrar, foi impedido e houve luta corporal 
entre ele e o segurança, que findou com o segurança sendo esfaqueado pelo chicano. A polícia, chamada imediatamente, prendeu o chicano em fuga, em flagrante, e providenciou a hospitalização do segurança que, na ocasião do fato observado, passava bem.

Diante do juiz, no fórum da cidade, o district attorney e o defensor público sentamse em lados opostos, em frente à mesa do juiz e em sua sala privada (chambers), para expor suas razões. O promotor alega que o chicano cometeu tentativa de homicídio, por ter esfaqueado o segurança que estava desarmado. A defesa alegava legítima defesa, pois a diferença de compleição física era gritante e o chicano dizia ter sido fisicamente agredido, tendo marcas dessa agressão em seu corpo. Além do mais, ele não falava inglês e não entendeu o que o segurança, que também não entendia espanhol, lhe dizia, e pensou que estava sendo barrado, e depois agredido, em razão de preconceito étnico, o que o enfureceu.

O juiz alega para as partes que aquele caso não possuía nem relevância, nem gravidade para ser objeto de um julgamento caro e demorado e sugeriu que as partes deveriam chegar a um acordo. Começou-se, então, a discutir tipos penais correspondentes a lesões corporais, graves ou leves, com suas respectivas consequências penais. $O$ promotor concordou em mudar sua acusação para lesão corporal grave. A defesa achou ainda muito forte a acusação, mas foi instada a consultar o acusado.

A proposta foi levada pela defesa ao acusado, que se encontrava preso no andar de baixo do fórum, no mesmo prédio. O acusado, entretanto, não concordou com a acusação, que implicaria pena de prisão mínima por dois anos e exigiu um trial by jury, mesmo que a acusação fosse de tentativa de homicídio. Tendo voltado à presença do juiz - que, nesse ínterim, atendera a outros casos presentes em sua pauta - com esse resultado, ele pressiona a acusação para que chegue a um consenso com a defesa. Após intenso debate, de que participaram a acusação, a defesa e o juiz, delineou-se outra proposta de lesão corporal leve, que implicava um ano de prisão e sursis, quer dizer, a pena seria cumprida em liberdade, com restrição de direitos e obrigações a serem acatadas pelo acusado. Levada esta proposta ao acusado, ele concorda e, uma semana depois, comparece diante do tribunal. Nessa ocasião, o juiz lê a acusação combinada de lesão corporal leve e pergunta a ele como se declara. Ele se declara guilty e em mais 15 dias volta ao tribunal para ouvir a sentença, também já estipulada na ocasião do acordo.

É claro que as situações nos EUA variam de acordo com os estados, os acusados, os defensores, os acusadores e os juízes, mas este é um bom exemplo de como o "tipo" penal, a verdade jurídica que prevaleceu, e não apenas a pena ${ }^{11}$, foi negociado, implicando a aceitação parcial dos argumentos do acusado, por um lado, mas também a sua condenação pelo crime praticado, por outro: em suma, "caiu nas malhas da lei", como costumam dizer os operadores da segurança pública. 
Nada a ver, portanto com uma disputa sobre uma verdade real, absoluta, que se quer impor à outra parte, que tem por opção ou concordar com ela, confessando, ou discordar dela, através de um dissenso infinito, presumidamente falso, ao opor-se aos argumentos da acusação, fundados em um inquérito que tem fé pública, a ser definida pela decisão de uma autoridade supostamente "de fora" do litígio o juiz. Ou de calar-se, caso em que a suspeita continua forte contra ela, pois "quem cala consente". No caso de San Francisco, o juiz interfere para forçar o consenso entre as partes e para livrar-se de um julgamento longo e caro - segundo palavras dele - no qual não cabia insistir em caso de pouca relevância social e moral, uma vez que a vítima passava bem e se recuperaria sem sequelas, segundo a notícia da perícia, e o chicano, de qualquer jeito, sofreria uma pena.

O exame dos dois casos também permite inferir efeitos e propostas distintas para a ética entre os profissionais do direito, observadas por mim no Brasil e nos EUA. No Brasil, a lógica do contraditório impõe uma instrumentalidade ao argumento, fazendo com que o mesmo advogado, dependendo do cliente, assuma posições radicalmente diferentes, seja no mesmo caso, seja em casos diversos. Também, como os acordos não são explícitos e dependem sempre da aprovação do juiz que dá a sentença, a promiscuidade entre advogados e promotores e, igualmente, o pertencimento a estas duas funções por uma única pessoa é considerado possível. Ao contrário dos EUA, como observei antes, em que a responsabilidade pelos acordos é das partes, elas constantemente se opõem em negociações duras para defender o interesse de seus constituídos.

Ora, ressaltam aqui dois sentidos de justiça, ou sensibilidades jurídicas, ou regimes de verdade, bastante opostos, fundados em premissas também largamente afastadas: num caso, há um Estado que, separado da sociedade, fiscaliza-a através de seus funcionários e, sigilosamente, está em permanente busca de erros e transgressões de seus componentes, sempre alvos de uma suspeita oficial e sistemática. Estes, uma vez identificados, são coletados em testemunhos e outros procedimentos, "reduzidos a termo" nos "autos" de um inquérito sigiloso para o acusado e para terceiros; escrito, elaborado e homologado por uma autoridade cartorária, o que lhe dá fé pública. ${ }^{12}$ Ao cabo, é enviado ao promotor, para que este, satisfeito com os seus elementos, faça a denúncia. Só então o acusado toma conhecimento da acusação, que já traz em si avançada presunção de sua culpa, devidamente consolidada. E claro que o resultado esperado desse procedimento é sua condenação, pois tudo aponta para isto. Sua confissão, nesse caso, não interrompe o processo, apenas servindo para atenuar sua pena. E, se não confessa, tem que enfrentar os argumentos com fé pública contra ele, para desconstruí-los, sempre sob a suspeita de serem mentirosas suas alegações ou seu silêncio. No final, uma autoridade judiciária, juiz ou jurados, alheia às partes, decide qual o resultado da demanda. Há nítida prevalência do Estado e de seus funcionários sobre a sociedade e seus componentes, em especial aqueles acusados de algum crime. 
No outro caso, as partes dispõem-se a negociar os fatos e a verdade que deverá prevalecer na frente da autoridade judiciária, que as dirige para um consenso, o qual porá fim aos procedimentos judiciais. A decisão maior está com as partes, que devem escolher uma acusação que as contemple, a qual será homologada pelo juízo. A sociedade e as suas decisões, neste caso, prevalecem sobre a decisão do Estado a qual, também, diga-se de passagem, seria tomada no trial by jury por árbitros, igualmente escolhidos pelas partes, que deveriam chegar a um consenso entre eles: os jurados.

Em outros lugares (Lima, 2009), elaborei dois modelos jurídicos para a sociedade (Geertz, 1989) - ideais e normativos, portanto - a que chamei de paralelepípedo e pirâmide. No paralelepípedo, onde o topo é igual à base, a sociedade era composta de indivíduos portadores de interesses diferentes, mas iguais em direitos, fato que os coloca em oposição e conflito permanentes. A desigualdade de status, assim, se dava em termos das escolhas melhores ou piores que os indivíduos faziam entre as opções disponíveis no elenco daquelas publicamente dadas. As regras eram sempre vistas como de origem e legitimidade localizada, limitadas a um universo definido. Tinham interpretação literal e aplicavam-se universalmente, de maneira uniforme, a todos. No caso da pirâmide, a base é maior que o topo. A sociedade é composta de segmentos desiguais e complementares que devem se ajustar harmonicamente. As regras são sempre gerais para toda a pirâmide, mas como se destinam a segmentos desiguais em direitos e interesses, devem ser aplicadas particularizadamente através de sua interpretação por uma autoridade.

Discuti também as consequências de sua maior ou menor incorporação a sociedades concretas, em termos de processos institucionais de administração de conflitos, de representações sobre os significados das leis e das regras, com reflexos óbvios nas ênfases que as estratégias de controle social assumiriam em casos concretos. Também explicitei que o caso brasileiro era bastante peculiar, porque incorporava em seu sistema de regras jurídicas princípios opostos, fundadores e articuladores de cada um dos dois modelos, sem que este paradoxo causasse, aparentemente, qualquer incômodo intelectual ou moral.

Ressalte-se que, inclusive, os modelos operam com ideias de igualdade bastante opostas: no paralelepípedo, a igualdade identifica-se com a diferença e os conflitos se dão entre iguais; na pirâmide, a igualdade identifica-se com a semelhança e os conflitos podem ocorrer entre pares e entre desiguais. Daí, a necessidade de ter procedimentos distintos para quando o conflito é entre iguais, ou entre desiguais, como parece ser o caso dos procedimentos judiciais prescritos para julgar os casos de homicídio e latrocínio, que mencionei acima (Oliveira, 2010).

Entretanto, essas diferenças processuais entre os modelos e dentro deles não são explicitadas. O máximo de tensão explícita que o sistema de administração judicial de conflitos admitia, no caso brasileiro, era uma oposição entre sistemas acusatórios e inquisitórios; discussão, aliás, própria dos sistemas da civil law, acima mencionados, referidos por Almeida Junior (1920). 
No entanto, estou convencido, seja pelos dados construídos etnograficamente, seja pela observação dos rituais judiciários e policiais, seja na observação e na interação com as práticas pedagógicas inculcadas nos profissionais do direito por sua educação jurídica, formal e informal, que é relevante, heuristicamente, situar a diferença na oposição de modelos judiciários que buscam o consenso (lógica adversária) e modelos fundados no dissenso (lógica do contraditório ${ }^{13}$ ).

Isto porque esses modelos, fundamentalmente, representam duas atitudes distintas diante das relações admissíveis entre o conhecimento apropriado particularizadamente e o seu papel no exercício do poder pela autoridade pública (Lima, 2010b). No caso da lógica do contraditório, o saber particularizado converte-se em poder em público e tem sinal positivo: quem está no vértice da pirâmide - de qualquer pirâmide (social, econômica, política, judiciária etc.) - exerce seu poder fundado no saber de que se apropriou particularizadamente, ao qual não tiveram acesso seus pares, pois pode inclusive dele se apropriar por meio de suas relações particulares. ${ }^{14}$ Os concursos públicos em geral e, em especial, os jurídicos são exemplo disto: para lograr aprovação, é necessário acesso a um conhecimento particularizado, que não está disponível no mercado universitário. Em consequência, quando conseguem passar, os aprovados sentem-se como que eleitos porque detentores de um saber especial, único, como que ungidos para tomar suas decisões livremente, sem que tenham que prestar contas senão a seus pares. No caso dos juízes, considerado o concurso mais "difícil” de todos, esta unção empresta efeitos oraculares ao seu "livre convencimento" (Foucault, 2005; Mendes, 2010). A educação pública e universal, portanto, não se constitui em um fator de inclusão, mas de exclusão progressiva daqueles que não terão acesso ao saber que realmente importa, seja por qual meio isso se verifique e atualize.

Por outro lado, no caso da lógica adversária, impõe-se que o saber particularizado seja neutralizado, ou até mesmo criminalizado, quando utilizado em público: é o caso das informações privilegiadas e os efeitos que seu uso no mercado de capitais determina a seus detentores, quando descoberta sua intervenção. $O$ saber só pode se constituir em poder quando está acessível a todos os interessados, que irão competir pelas melhores escolhas para o seu emprego. Assim, a educação é includente na competição, pois socializa as pessoas a reagirem negativamente ao uso público de informações apropriadas de maneira particular, como mencionei alhures (Lima, 2010b).

Outra consequência é que os conceitos que se baseiam nas formas de convencimento, entendimento (understanding) e persuasão pela argumentação mostram-se inadequados para analisar o que ocorre no mundo do direito brasileiro, pois estão fundados na prévia e suposta igualdade dos interlocutores. Aqui, dada a desigualdade legal e explícita entre os interlocutores, é o argumento de autoridade que prevalece na administração dos conflitos e não a autoridade do 
argumento, que convence as partes envolvidas. Isto se reflete também nos debates jurídicos e políticos, que levam a que decisões coletivas se constituam na soma de decisões singulares, mesmo quando elas são proferidas em espaços coletivos, como os tribunais de segunda e terceira instâncias. Os saberes particulares não precisam do consenso, e nem o desejam, para concordar, porque o consenso não legitima, pelo contrário, "contamina" suas formas particularizadas de acessar o conhecimento jurídico. ${ }^{15}$

Assim, como já salientei antes, misturam-se, oficial e legalmente, sensibilidades jurídicas de caráter muito diverso, o que colabora para tornar o sistema jurídico empírico, opaco aos próprios operadores, que não dispõem de orientações universais que devam prevalecer em todos os casos. As duas ideias de igualdade, uma associada à semelhança, outra à diferença, sustentam, de certa maneira, a possibilidade de um eterno uso da lógica do contraditório, em que a decisão nunca é das partes envolvidas, mas daqueles que detêm a autoridade, fundada em um saber apropriado particularizadamente, de origem mágica, que é a fonte de seu poder e da legitimidade de suas decisões. ${ }^{16}$

Essa contradição oficializada estabelece, então, uma confusão entre os interesses públicos - atribuídos não só ao Estado, mas a seus funcionários e os interesses da sociedade, do público em geral, no sentido de interesses sociais. Tal confusão faz com que, dotados de autoridade, os funcionários públicos, inclusive, se julguem com a capacidade de substituir os interesses dos hipossuficientes, isto é, daqueles cidadãos que supostamente não conhecem seus direitos e, por isso, não podem exercitá-los, ou seja, dos cidadãos que ignoram, que não têm conhecimento de seus direitos e por esta razão não os exercem, como se o simples conhecimento se confundisse com o seu exercício.

Conceito e atuação não muito distante das justificativas para a permanência da "inquisitorialidade", fundada na prevalência dos interesses públicos sobre aqueles privados. O que não se explicita é que tais interesses públicos são particulares do Estado, que não se confunde, nem quer se confundir, com a totalidade da sociedade, dotada afinal de hipossuficiência contaminadora da sabedoria particularizadamente adquirida (Mouzinho, 2007).

É claro que estamos diante de dois mitos de legitimação da normatividade e de seus agentes. Em um deles, a origem social do direito, confundido com a lei, engloba em uma mesma categoria linguística - Law - as duas esferas da normatividade, propondo sua subordinação não aos desígnios do Estado, mas aos interesses da sociedade. É a sensibilidade do Rule of Law. No outro, a legitimação se dá por um saber particularizado, pertencente a uma elite que reivindica seu poder de decisão sobre a sociedade, através de seu pertencimento e de sua fusão com o Estado: é a Rule by Law (Garapon \& Papadopoulos, 2008). 
O caso brasileiro, entretanto, permite sugerir que nem o regime de verdade da disciplina se constituiu como expressão jurídica ou extrajurídica de formas de controle social total pelo saber que a vigilância proporciona (Oliveira, 2010a, 2010b), nem muito menos o do inquérito, com sua mítica separação entre o saber e o poder. Por fim, nosso modelo jurídico para a sociedade, para a administração institucional de conflitos e para o exercício do controle social acaba por associar, legítima e legalmente, o saber ao poder, atribuindo o papel de decifradores oficiais de enigmas aos operadores da nossa justiça, como se esta habilidade fosse a única e legítima origem de seu poder, como era o caso de Édipo, antes do inquérito, na versão foucaultiana do mito.

\section{Notas}

* Agradeço o convite do professor Luís Roberto Cardoso de Oliveira para escrever e publicar este artigo e organizar um dossiê, neste Anuário Antropológico, depois de uma longa ausência de suas páginas (Lima, 1991). Agradeço também aos colegas que comentaram o texto antes desta versão: Ana Paula Mendes de Miranda, Bárbara Lupetti Baptista, Marco Aurélio Gonçalves Ferreira e Regina Lúcia Teixeira Mendes. Destes comentários, muito atentos, substanciais, valiosos e gentis, incorporei o que foi possível. O impossível demora mais um pouco.

1. Art. 121. Matar.alguém: Pena - reclusão, de 06 (seis) a 20 (vinte) anos; Parágrafo segundo: Se o homicídio é cometido: I - mediante paga ou promessa de recompensa, ou por outro motivo torpe; II - por motivo fútil; III - com emprego de veneno, fogo, explosivo, asfixia, tortura ou outro meio insidioso ou cruel, ou de que possa resultar perigo comum; IV - à traição, de emboscada, ou mediante dissimulação ou outro recurso que dificulte ou torne impossíveladefesa do ofendido; $\mathrm{V}$-paraassegurara execução,a ocultação,aimpunidade ou vantagem de outro crime: pena - reclusão, de 12 a (doze) a 30 (trinta) anos (Brasil, 2001; grifo meu).

Art. 157 - Subtrair coisa móvel para si ou para outrem, mediante grave ameaça ou violência à pessoa, ou depois de havê-la, por qualquer meio, reduzido à impossibilidade de resistência. Parágrafo Terceiro: Se da violência resulta lesão corporal grave [...]; se resulta morte, a reclusão é de 20 (vinte) a 30 (trinta) anos, sem prejuízo da multa (Brasil, 2001).

2. Ana Paula Mendes de Miranda chama a minha atenção para o fato de que há, também, categorias policiais que desigualam o tratamento dos homicídios, como aquelas que os enquadram na classificação de autos de resistência. Nesses casos, quando o policial mata, presume-se que o fez em legítima defesa. Muitas vezes, no entanto, investigações posteriores concluem que os autos de resistência foram forjados, como foi o caso de recentes procedimentos do Ministério Público estadual no município de São Gonçalo, RJ.

3. Em alguns casos, no trial by jury a unanimidade é requerida. 
4. No sentido weberiano do conceito.

5. Regina Lúcia Teixeira Mendes chama a minha atenção para o fato de que o princípio do livre convencimento do juiz é princípio processual que se refere à avaliação de determinado conjunto probatório. $\mathrm{Na}$ representação dos operadores, ele se torna uma categoria que explicita esta finalidade do processo brasileiro: o convencimento do juiz. Há o princípio constitucional (art. 93, IX) da obrigatoriedade imposta ao juiz de fundamentar sua decisão explicitando na sentença ou no acórdão os motivos que o levaram a decidir daquela maneira: Constituição, Art. 93. Lei complementar, de iniciativa do Supremo Tribunal Federal, disporá sobre o Estatuto da Magistratura, observados os seguintes princípios: IX todos os julgamentos dos órgãos do Poder Judiciário serão públicos, e fundamentadas todas as decisões, sob pena de nulidade, podendo a lei limitar a presença, em determinados atos, às próprias partes e a seus advogados, ou somente a estes (Brasil, 1989).

6. Alguns juristas brasileiros, provavelmente influenciados pela leitura de Malatesta (2009), definem o sistema de prova legal como uma prova que se produz no inquérito, mas que é previamente tarifada, deixando pouca margem de decisão ao julgador. Para Foucault, trata-se de testes a que se submetem as partes para que as divindades decidam quem tem razão.

7. Circunstância que remete à contemporânea categoria da hipossuficiência. Voltarei ao assunto.

8. Não é demais comentar que esta ideia é atualizada pelos autores do mundo contemporâneo, que escrevem para preparar operadores para as carreiras jurídicas, a exemplo Fernando Capez, o qual proclama o sigilo do inquérito "como forma de garantia da intimidade do acusado, resguardando-se, assim, seu estado de inocência” (Capez, 2008:77).

9. Bárbara Lupetti Baptista (2008) chama a minha atenção para o fato de que, no processo civil brasileiro, o depoimento pessoal da parte não tem valor algum, porque se pressupõe que a parte vai mentir, já que está interessada em defender a sua "tese". Já no depoimento da testemunha existe uma tipificação da mentira (falso testemunho). Assim, se verifica que para o depoimento pessoal da parte existe uma pressuposição da mentira que leva à estigmatização do seu depoimento e à sua consequente desqualificação na fase instrodutória do processo. Na Constituição de 1988 (Brasil, 1989; LXIII, art. 5.), institui-se o direito ao silêncio, logo interpretado extensivamente, associando-o ao princípio nemo tenetur se detegere, ou seja, o direito de não produzir prova contra si mesmo.

10. Marco Aurelio Gonçalves Ferreira chama a minha atenção para o fato de que a racionalidade da doutrina brasileira se apresenta oposta ao direito anglo-saxão, na medida em que, a exemplo do que afirma o autor Luiz Flávio Gomes, o nosso sistema jurídico admite a mentira do acusado como uma das hipóteses de não-autoincriminação (Ferreira, 2009; Gomes, 2008).

11. Como na transação penal prevista na lei 9099/95, dos Juizados Especiais Criminais (Brasil, 1995).

12. Para uma discussão sobre a elaboração desse inquérito e seus efeitos no saber policial de investigação, ver Lima, 2010a e Misse (org.), 2010. 
13. Não confundir a lógica do contraditório com o princípio do contraditório. O princípio do contraditório é garantido na Constituição da República de 1988 (Brasil, 1989), em seu artigo $5^{\circ} .:$ Art. $5^{\circ}$ - Todos são iguais perante a lei, sem distinção de qualquer natureza, garantindo-se aos brasileiros e aos estrangeiros residentes no País a inviolabilidade do direito à vida, à liberdade, à igualdade, à segurança e à propriedade, nos termos seguintes: LV aos litigantes, em processo judicial ou administrativo, e aos acusados em geral são assegurados o contraditório e ampla defesa, com os meios e recursos a ela inerentes.

14. Como mencionei acima, quando comentava minha dificuldade de acesso à bibliografia sobre o Tribunal do Júri, no Brasil, em contraste com a disponibilidade dos textos brasileiros na Harvard University, nossas bibliotecas públicas pífias e nossas exuberantes bibliotecas particulares são uma expressão desta regra: quem sabe mais teve acesso privilegiadoao conhecimento, então pode mais.

15. Como aconteceu recentemente de forma exemplar, no caso da chamada "lei da ficha suja”, que colocou impedimento ao registro de candidatos às eleições de 2010. Discutiu-se sua aplicabilidade, ou não, às eleições do mesmo ano em que foi promulgada. Não somente a controvérsia não foi resolvida, porque o STF empatou em 05 votos a 05 , como os argumentos - e "votos" - dos ministros, tanto os que votaram a favor, como os que votaram contra, foram completamente dissonantes sobre vários assuntos.

16. Impossível não referir aqui a discussão de DaMatta, 1997. 


\section{Referências bibliográficas}

ALMEIDA JUNIOR, João Mendes de. 1920. O processo criminal brazileiro. Vol 1. 3. ed. Rio de Janeiro: Typ. Baptista de Souza.

BAPTISTA, Barbara Gomes Lupetti. 2008. Os rituais judiciários e o princípio da oralidade: construção da verdade no processo civil brasileiro. Porto Alegre: Sérgio Antônio Fabris.

BERMAN, Harold Joseph. 1983. Law and revolution: the formation of the western legal tradition. Cambridge: Havard University Press.

- 2003. Law and Revolution II: the impact of the protestant reformatons on the western legal tradition. Cambridge: Harvard University Press;

The Belknap Press.

BOURDIEU, Pierre. 1996. A economia das trocas linguísticas: o que falar quer dizer. São Paulo: Editora da Universidade de São Paulo.

. 2009. "A força do direito: elementos para uma sociologia do campo jurídico". In: O Poder Simbólico. 12. ed. Rio de Janeiro: Bertrand Brasil. pp. 209-254.

BRASIL. 1989. Constituição brasileira 1988. 2. ed. rev. Rio de Janeiro: Forense.

. 1995. Lei 9099, 26 de setembro de 1995. Dispõe sobre os Juizados Especiais

Cíveis e Criminais e dá outras providências. Diário Oficial [da] República Federativa do Brasil. Brasília, DF, 27 set. 1995, Seção 1, p. 15033.

. 2001. Código Penal. 39. ed. São Paulo: Saraiva.

CAPEZ, Fernando. 2008. Curso de Processo Penal. 15. ed. rev. São Paulo: Saraiva.

DAMATTA, Roberto. 1997. "Você sabe com quem está falando?: um ensaio sobre a distinção entre indivíduo e pessoa no Brasil”. In: . Carnavais, malandros e heróis: para uma sociologia do dilema brasileiro. 6. ed. Rio de Janeiro: Rocco. pp. 181-248.

DAVIS, Shelton H. 1973. Antropologia do direito: estudo comparativo de categorias da dívida e contrato. Rio de Janeiro: Zahar.

DAWSON, John Philip. 1960. A history of law judges. Cambridge: Harvard University Press.

ECO, Umberto. 1986. O nome da Rosa. Rio de Janeiro: Record.

FERREIRA, Marco Aurélio Gonçalves. 2009. Contrastes e confrontos: a presunção de inocência e as garantias do processo penal em perspectiva comparada. Tese de Doutorado em Direito, Universidade Gama Filho.

FIGUEIRA, Luiz Eduardo. 2008. O ritual judiciário do tribunal do júri. Porto Alegre: Sérgio Antonio Fabris Editora.

FLORY, Thomas. 1981. Judge and Jury in Imperial Brazil, 1808-1871. Social control and political stability in the new state. Austin: University of Texas Press. 
FOUCAULT, Michel. 2005. A verdade e as formas jurídicas. 3. ed. Rio de Janeiro: Nau Editora. GARAPON, Antoine \& PAPADOPOULOS, Ioannis. 2008. Julgar nos Estados Unidos e na França: cultura jurídica francesa e common law em uma perspectiva comparada. Rio de Janeiro: Lumen Júris. GARCIA BARBERENA, Tomas \& ALONSO MORAN, Sabino. 1964. "Cânone número 1943". In: Comentarios al codigo de derecho canônico: Canones 1322-1998. Madrid: BAC. v.3. pp. 668 .

GEERTZ, Clifford. 1989. “Uma descrição densa”. In: . A interpretação das culturas. Rio de Janeiro: Editora Guanabara. pp. 13-41.

. "O saber local: fatos e leis em uma perspectiva comparativa". 2006. In: O

Saber Local: novos ensaios em antropologia interpretativa. 8. ed. Petrópolis: Vozes. pp.249-356.

GODELIER, Maurice. 1968. Racionalidade e irracionalidade na economia. Rio de Janeiro: Tempo Brasileiro.

GOMES, Luiz Flávio. 2008. O direito ao silêncio e as investigações. CCJ do Senado rasga (uma vez mais) a Constituição brasileira. Jus Navigandi, Teresina, 13(1982), 4 dez. 2008. Disponível em: <http://jus2.uol.com.br/doutrina/texto.asp?id=12041>. Acesso em: 16/06/2009.

KAPLAN, Benjamin. 1972. "Trial by Jury”. In: Harold Berman (ed.). Talks on American Law: a series of broadcasts to foreign audiences by members of the Harvard Law School. New York: Vintage Books. pp. 51-62.

LIMA, Roberto Kant de. 1991. "Ordem pública e pública desordem: modelos processuais de controle social em uma perspectiva comparada (inquérito e jury system)”. Anuário Antropológico, n. 88:21-44, Brasília.

1995. Da inquirição ao júri, do trial by jury a plea bargaining: modelos para a produção da verdade e a negociação da culpa em uma perspectiva comparada (Brasil/Estados Unidos). Tese para Professor Titular da Universidade Federal Fluminense.

. 2009. "Saber jurídico e direito à diferença no Brasil: questões de teoria e método em uma perspectiva comparada". In: - Ensaios de Antropologia e de Direito. 2. tir. Rio de Janeiro: Lumen Júris. pp. 89-126.

. 2010a. A polícia da cidade do Rio de Janeiro: seus dilemas e paradoxos. Rio de Janeiro: Lumen Júris. No prelo. 2010b. A Antropologia da Academia. 3. ed. Niterói: EDUFF. No prelo.

MALATESTA, Nicola Framarino dei. 2009. A lógica das provas em matéria criminal. Campinas, SP: Ressell Ed.

MCCART, Samuel W. 1964. Trial by Jury: a Complete Guide to the Jury System. New York: Clinton Books. 
MENDES, Regina Lucia Teixeira. 2010. Do princípio do livre convencimento motivado: Legislação, Doutrina e interpretação de juízes brasileiros. 1. ed. Rio de Janeiro: Lumen Júris. No prelo.

MIRANDA, Ana Paula Mendes de e LIMA, Lana lage da Gama (orgs.). 2008. Políticas Públicas de Segurança, Informação e Análise Criminal. Niterói: EDUFF

MISSE, Michel (org.) . 2010. O inquérito policial no Brasil: uma pesquisa empírica. Rio de Janeiro: NECVU/IFCS/UFRJ; Booklink; FENAPEF

MOTA, Fabio Reis e MIRANDA, Ana Paula Mendes de (orgs.). 2010. Práticas Punitivas, Sistema Prisional e Justiça. Niterói: EDUFF

MOUZINHO, Gláucia Maria Pontes. 2007. Sobre culpados e inocentes: o processo de incriminação e incriminação pelo Ministério Público Federal brasileiro. Tese de Doutorado em Antropologia, Universidade Federal Fluminense.

OLIVEIRA, Luís Roberto Cardoso de. 2010a. "Concepções de igualdade e desigualdades no Brasil (uma proposta de pesquisa)". In: Roberto Kant de Lima, Lucía Eilbaum \& Lenin Pires (orgs.). Conflitos, Direitos e Moralidades em Perspectiva Comparada. Vol I. Rio de Janeiro: Garamond. pp. 19-33.

. 2010b. A Dimensão Simbólica dos Direitos e a Análise de Conflitos. Artigo aceito para publicação na Revista de Antropologia, volume 53(2).

PARRY, L.A. 1975. The History of Torture in England. Montclair: Patterson Smith.

PIRES, Lenin e EILBAUM, Lucia (orgs.). 2009. Políticas Públicas de Segurança e Práticas Policiais no Brasil. Niterói: EDUFF

WEBER, Max. 1978. Economy and Society:An Outline of Interpretive Sociology. Edited by Guenther Roth and Claus Wittich. 2. vols. Berkeley: University of California Press. 


\section{Resumo}

Neste artigo, discuto resultados de pesquisas que venho realizando nos últimos 20 anos, referentes à compreensão e à aplicação do conceito de Clifford Geertz sensibilidade jurídica - a diferentes contextos jurídicos ocidentais. Após sucessivas e cumulativas propostas de interpretação, cheguei a algumas conclusões, que me levam a propor alternativas e correções nas proposições que tanto eu como outros fizemos sobre as questões em pauta, pois as etnografias realizadas, embora inspiradas nessas discussões, foram abrindo portas para que outros aspectos das sensibilidades jurídicas ocidentais se explicitassem.

Inicialmente, recapitulo os passos da pesquisa; depois, apresento os dados etnográficos construídos e aponto as insuficiências de alguns aspectos dos modelos teóricos interpretativos vigentes; finalmente, proponho outros modelos, de maior potencial interpretativo, cuja crítica, certamente, não tardará.

\section{Palavras-chave}

Sensibilidades jurídicas, sentidos de justiça, processos institucionais de administração de conflitos, antropologia do direito, método comparativo aplicado ao direito.

\section{Abstract}

This article discusses findings of last 20 years' ethnographic research which have been conducted either by me or under my supervision, applying critically Geertz's concept of legal sensibility to different Western legal contexts. Based on these ethnographies' results, some critical conclusions are presented and alternative and complimentary interpretations are provided. At first, research developments will be described, followed by presentation of ethnographic data and criticisms to some current theoretical models which were used to approach the problems at stake. Finally, I will propose other interpretive models which, of course, will be soon criticized and outdated.

\section{Key words}

Legal sensibilities, institutional processes of conflict administration, anthropology of law, comparative method applied to law. 